3. Освещение ландшафтных объектов. Акцент на растения и деревья повышает привлекательность набережной. Для данного освещения можно использовать прожектора, расположенные на уровне земли. Это придаёт таинственной атмосферы, так как создаётся иллюзия, что предмет ландшафта сам излучает свет, а не является предметом освещения.

4. Освещение малых архитектурных форм. В этом случае используется подсветка, либо малая архитектурная форма может являться самостоятельным источником света.

5. Световая инсталляция. Данный приём может быть не только источником света, но и стать динамичным представлением, что будет привлекать посетителей.

6. Подсветка фасадов прилегающих зданий и сооружений. Такой приём используется, если вдоль территории набережной расположены здания и сооружения, имеющие красивые архитектурные особенности.

\title{
Заключение
}

На основе проведённого анализа можно сделать вывод о том, что освещение набережных является важной составляющей для вечернего и ночного времяпровождения. Современные подходы при проектировании светового дизайна могут создавать различные сценарии с помощью освещения. Для создания спокойной романтической атмосферы, вечерних прогулок и тихого отдыха - будет создано минимальное освещение, подсветка малых архитектурных форм, различные скрытые и встроенные светильники, которые не бросаются в глаза, а в другом случае, когда нужно создать ощущение праздника, величественности, притяжение взглядов, то освещение будет намного ярче и динамичнее.

1. Освещение бульваров, скверов, парков, набережных - URL: https://armadasvet.ru/stati/ulichnoeosveshhenie/osveshhenie-bulvarov-skverov-parkov-naberezhnyix.html.

2. Опыт освещения набережной реки Енисей в Красноярске - URL: https://ledvizor.ru/publications/opytosvescheniya-naberezhnoy-reki-enisey-v-krasnoyarske.

3. Современная набережная польского городка Тыхы - URL: https://arch-sochi.ru/2015/10/sovremennayanaberezhnaya-polskogo-gorodka-tyihyi-tychy/.

4. Лучшая Набережная В России - URL: https://bestlj.ru/102328-Luchshaja-naberezhnaja-v-Rossii.html.

\section{Пыренкова Е.А. \\ Использование многолетних трав в озеленении и оценка их декоративности по морфологическим признакам}

Российский Государственный Аграрный Университет МСХА им К.А Тимирязева (Россия, Москва)

doi: 10.18411/trnio-01-2022-232

\section{Аннотация}

Данная статья посвящена актуальности использования многолетних травянистых растений в городском озеленении, а также методики оценки их декоративности. Это неприхотливые растения устойчивые к суровым условиям загазованности города. Целью статьи является обзор положительных и отрицательных качеств трав, как посадочного материала, на другие растения и визуальную среду вокруг человека на протяжении всего года.

Ключевые слова: декоративные травы, ландшафт, многолетние растения,
декоративность.

\section{Abstract}

This article is devoted to the relevance of using perennial herbaceous plants in urban landscaping, as well as methods of assessing their ornamental value. They are unpretentious plants 
resistant to the harsh conditions of city pollution. The purpose of the article is to review the positive and negative qualities of grasses as a planting material, on other plants and the visual environment around people throughout the year.

Keywords: ornamental grasses, landscape, perennial plants, ornamentalism.

Травы являются одними из самых знаковых растений природных ландшафтов, которые растут везде и всюду. В наших городских ландшафтах они добавляют движение и текстуру с лета до зимы и даже создают красивую картину, когда их шлейфы освещаются солнцем. Сегодня сохранилось лишь несколько нетронутых естественно-природных лугов, но мы все равно ценим то вдохновение, которое они могут привнести в идеи озеленения нашего города.

Декоративные травы, посаженные большими массами или среди кустарников и многолетников, добавляют движение и интересную текстуру, которая хорошо контрастирует с зелеными, лиственными многолетниками и кустарниками. Среди трав очень много видов, и они предлагают захватывающее разнообразие высоты, ширины и цветения для различных стилей и функций в дизайне.

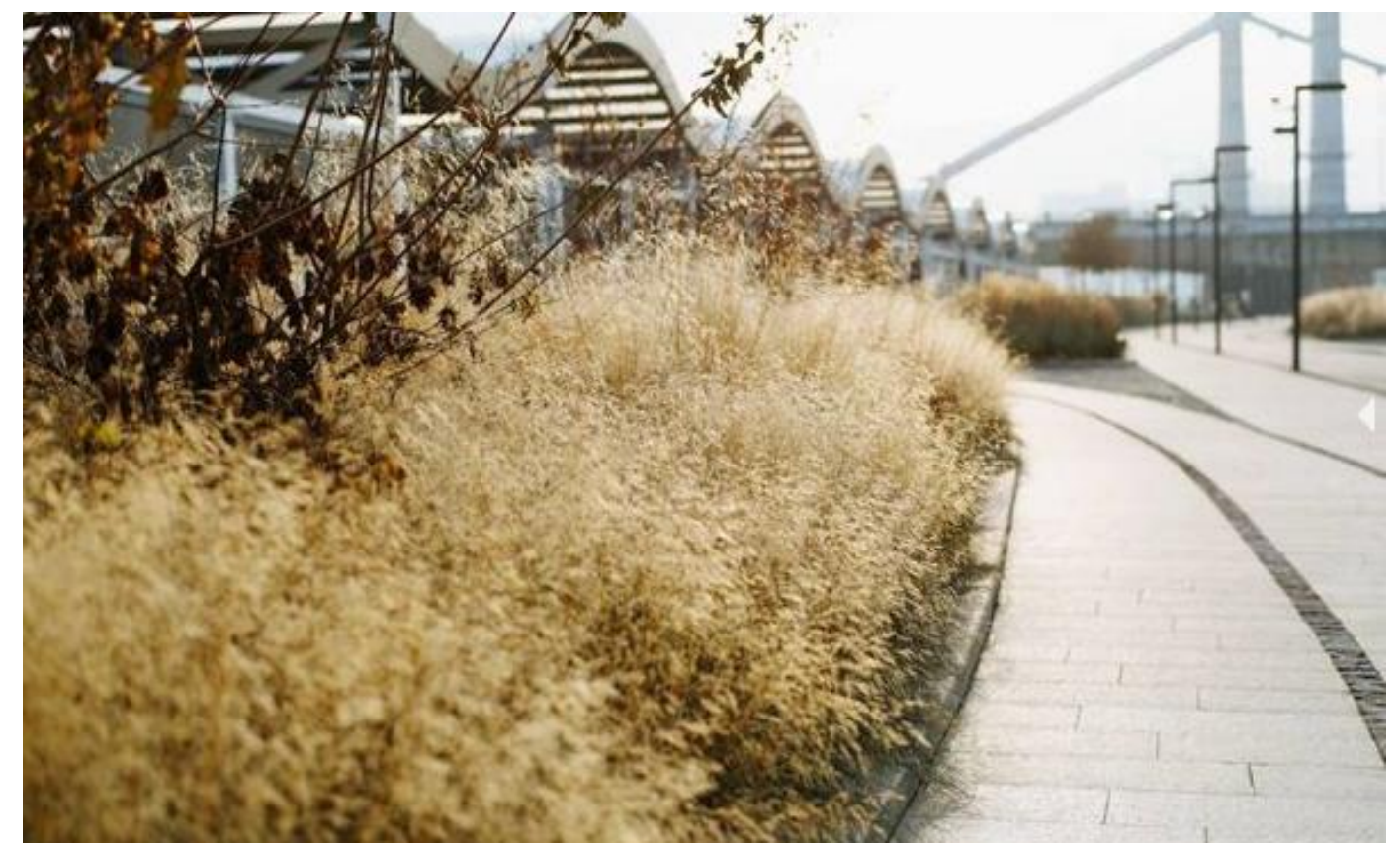

Рисунок 1. Набережная парка «Музеон». Фото от 02.10.2021

Декоративные травы и травоподобные растения ценятся ландшафтах за их выносливость, простоту ухода, эффектный внешний вид и широкий выбор цветов, текстур и размеров.

К декоративным травам относятся как настоящие травы, так и растения, внешне напоминающие траву, например, осоки, которые используются в садах для аналогичных целей.

Большинство декоративных трав - многолетние растения, живущие два или более лет. Однолетние травы живут только один вегетационный сезон из-за их естественной привычки роста или из-за того, что они не выносливы в нашем климате.

По характеру роста травы бывают кустистыми и раскидистыми. Травы быстро разрастаются за счет надземных или подземных стеблей. При посадке обильно пышных трав следует соблюдать осторожность, так как они могут заглушить уже имеющиеся посадки. Разрастающиеся или пучковые травы растут комками, постепенно увеличивающимися в диаметре.

Большинство декоративных трав, высаживаемых, например, на юге, классифицируются как растения холодного или теплого сезона. Травы холодного сезона 
начинают новый рост осенью или зимой и цветут весной или в начале лета. Во время летней жары они впадают в спячку или теряют вид. Большинство декоративных трав для относятся к растениям теплого сезона. Они быстро растут весной и летом, цветут в конце лета или осенью, а зимой находятся в состоянии полного покоя, оставляя сухоцвет.

Декоративные травы различаются по высоте: от тех, что достигают около 4 метров в высоту, до более низкорослых трав, которые используются в качестве почвопокровных. Формы травы варьируются от низких насыпей до фонтанов и высоких вертикалей достигаемых, как правило, соцветиями.

Соцветия различаются по размеру, цвету и текстуре. Они сохраняются в течение нескольких недель или месяцев, и многие сорта за счет высохших соцветий придают улицам, скверам и паркам декоративный вид в течении всей зимы.

Листва также часто привлекает внимание и интерес: от мелко- до крупнозернистых листовых пластин, мягко аркообразные или вертикальные формы, насыщенный зеленый, синий, красный или пурпурный, желтый или пестрый цвет листьев. Многие травы имеют яркую осеннюю окраску, меняющуюся на золотисто-желтую, оранжевую, красную или пурпурную, а затем увядающую на зиму до оттенков загара или соломы.

Травы также придают интерес саду так, как немногие другие растения. Они легко колышутся на ветру, придавая ландшафту привлекательность движений, ритма и игры красок и текстур. Их быстрый рост и изменение внешнего вида в течение года придают им максимальную декоративность.

Поскольку травы являются столь разнообразной и обширной группой, их можно использовать в различных ландшафтных целях. Высокие травы с ярким цветом листвы или цветов можно использовать в качестве акцентных растений и даже солитерных посадок. Ими можно заменить более мелкие кустарники, использовать в многолетних бордюрах и в контейнерных посадках и миксбордерах. В массе некоторые травы могут стабилизировать и укрепить почву на склонах холмов для борьбы с эрозией. К примеру, это актуально для берегов рек или озер если их берега не укреплены искусственно.

Существует ряд нежелательных инвазивных или агрессивных декоративных трав, которые обычно используются в ландшафте, таких как:

- $\quad$ мискантус китайский (Miscanthus sinense);

- $\quad$ пампасная трава (Cortaderia selloana);

- $\quad$ японский кровохлебка или императа цилиндрическая (Imperata cylindrica 'Rubra');

- $\quad$ гигантский тростник (Arundo donax);

- $\quad$ плакучий любисток или поливичка согнутолистная (Eragrostis curvula).

Эти травы свободно размножаются и не рекомендуются для использования в ландшафте из-за их способности уходить в естественную среду. Это, в свою очередь, вытеснит местные травы и растения, которые важны как источник пищи для опыляющих насекомых и других диких животных. Например, японская кровохлебка превратится в сильно инвазивную зеленую форму, поэтому использование этих видов встречается крайне редко.

(Былов В.Н., 1978). Оценка декоративной ценности растений проводится в период массового цветения по сто-бальной системе с коэффициентами. Оценку проводят дифференцированно по важнейшим декоративным признакам.

- $\quad$ Окраска соцветия - высшая оценка дается за чистую, яркую или нежную окраску язычковых цветков, создающих основной фон соцветия, низшая - за тусклую, грязную окраску этих цветков.

- $\quad$ Размер и форма соцветия - высшая оценка за размер соцветия и форму, несколько большую, нежели средний размер соцветия соответствующей группы; низший балл получает сорт, имеющий диаметр соцветия меньше среднего диаметра соответствующей группы. 
- К Куст (форма, декоративность) - высший балл сорт получает в том случае, когда куст имеет красивую колонновидную или канделябровидную форму, не разваливается, хорошо облиствен.

- Устойчивость соцветий к неблагоприятным метеорологическим условиям высший балл сорт получает, если после влияния неблагоприятных факторов соцветие сохраняет свою первоначальную форму и окраску; низший балл получает сорт, у которого куст разваливается, соцветия теряют свою первоначальную окраску и форму.

- Оригинальность - высшую оценку сорт получает за совершенно новую окраску и форму соцветия, низшую - если соцветие имеет окраску и форму, свойственную сортам этой группы.

- Состояние растений - высший балл, когда все растения имеют здоровый вид, полностью отсутствуют выпады в опыте; низший - если выпады составляют 10\% (глазомерно) и растения имеют несколько угнетенный вид.

При оценке декоративности растения в зависимости от значимости признака для каждого вида установлен свой переводной коэффициент. Каждый признак декоративности оценивают в пределах пятибалльной шкалы. В дальнейшем баллы (по каждому признаку в отдельности) перемножают на переводной коэффициент (степень значимости признака) и полученный результат, который является окончательной оценкой признака, заносят в соответствующую графу карточки оценки декоративности (табл. 1).

Таблииа 1

Примерная карточка оценки декоративной цеенности травянистых растений. Для сортов,

\begin{tabular}{|c|c|c|c|}
\hline Название признака & $\begin{array}{c}\text { Оценка признака по } \\
\text { пятибалльной } \\
\text { системе }\end{array}$ & $\begin{array}{c}\text { Переводной } \\
\text { коэффициент в } \\
\text { зависимости от } \\
\text { значимости } \\
\text { признака }\end{array}$ & $\begin{array}{c}\text { Оценка признака по } \\
\text { стобалльной } \\
\text { системе (max) }\end{array}$ \\
\hline 1.Окраска соиветий & om1 до 5 & 2 & 20 \\
\hline $\begin{array}{c}\text { 2. Устойчивость соиветий } \\
\text { к неблагоприятным } \\
\text { метеорологическим } \\
\text { условиям }\end{array}$ & om 1 до 2 & 2 & 2 \\
\hline 3. Форма соиветия & om 1 до 3 & 3 & 3 \\
\hline 4. Bысота растения, см & om1 до 5 & 5 & 25 \\
\hline 5. Размер листа, см & om 1 до 3 & 5 & 15 \\
\hline $\begin{array}{c}\text { 6.Куст (форма, } \\
\text { декоративность) }\end{array}$ & от1 до 5 & 3 & 15 \\
\hline 7. Оригинальность & om 1 до 2 & 2 & 4 \\
\hline $\begin{array}{l}\text { 8. Состояние растений } \\
\text { (выравненность сорта) }\end{array}$ & om 1 до 2 & 2 & 4 \\
\hline Итого: & & & Сумма: \\
\hline
\end{tabular}

Таким образом, применяя в озеленении многолетние травянистые растения мы получаем широкий спектр градации декоративных качеств и возможностей игры с текстурой, цветом, формой, композицией и ее этажностью. Легкая струящаяся фактура растений придает «бетонным джунглям» воздуха и жизни почти что круглый год. Будучи неприхотливыми растениями уход за посадками в общественных местах сводится к минимум и производится в основном при смени сезона. 
2. Ханбабаева О.Е., Березкина И.В. Методика сравнительной сортооценки декоративных культур. Научная жизнь. 2020. Т. 15. № 6 (106). С. 734-742.

3. Ханбабаева О.Е., Джус П.О. Перспективы озеленения урбанизированных территорий. В сборнике: Фундаментальные и прикладные исследования по приоритетным направлениям биоэкологии и биотехнологии. Сборник материалов III Всероссийской научно-практической конференции. Гл. редактор Е.И. Антонова. 2020. С. 86-90.

4. Ханбабаева, О.Е. Изучение биологических особенностей однолетних цветочных культур при различных типах посадки / О.Е. Ханбабаева, И.В. Берёзкина, А.С. Мазаева // Научная жизнь. - 2018. - № 8. - С.97-105.

5. Shlapakova S.N., Beriozkina I.V., Hanbabayeva O.E., Sorokopudov V.N., Lukashov Ye.S. SELECTION OF HERBACEOUS PLANT ASSORTMENT FOR PARK GROUND COVER USING PLANTS OF NATURAL PHYTOCOENOSIS. В сборнике: BIO Web of Conferences. International Scientific-Practical Conference “Agriculture and Food Security: Technology, Innovation, Markets, Human Resources” (FIES 2019). 2020. C. 00246. 